\title{
Erasmus+ Mobility: Empirical Insights into Erasmus+ Tourists' Behaviour
}

\author{
Miha Lesjak \\ University of Primorska, Turistica - Faculty of Tourism Studies, Slovenia \\ miha.lesjak@fts.upr.si \\ Emil Juvan \\ University of Primorska, Turistica - Faculty of Tourism Studies, Slovenia \\ emil.juvan@fts.upr.si \\ Eva Podovšovnik \\ University of Primorska, Turistica - Faculty of Tourism Studies, Slovenia \\ eva.podovsovnik@fts.upr.si
}

Erasmus+ students represent a large sub-segment of educational tourists, making this segment an attractive market for universities as well as destination marketing organisations. Unfortunately, very little is known about Erasmus+ students' travel behaviour; hence the present study aims at extending empirically supported knowledge about travel behaviour of students during their Erasmus+ mobility. Data was collected via an online survey among all Erasmus+ enrolling students in the academic year 2016/17 in Slovenia. The results show that 93\% of the participants travelled during their mobility. The level of studies as well as gender affect students' travel behaviour, making the two characteristics immediately useful attributes when targeting Erasmus+ travellers. Based on perceived destination attributes, male students predominantly seek cities with attractive nightlife but female students look for easily accessible cities, which are safe and offer attractive cultural sites. These findings suggest that tourism providers, destination tourism organisations and universities should work hand in hand when designing personalised tourism experiences and their promotion among Erasmus+ students. This is crucial during the phase of planning Erasmus+ mobility, when students choose their destination and host university, as well as during students' Erasmus+ mobility, because Erasmus + students travel during their student mobility.

Keywords: Erasmus+ mobility, education, international students, destination attributes, tourist behaviour

(cc)BY-SA https://doi.org/10.26493/2335-4194.13.35-50

\section{Introduction}

Student mobility involves an increasingly large population of students. The volume of student mobility worldwide exploded from 2 million in 1999 to 5 million in 2016 (Organization for Economic Cooperation and Development, 2018). In the oECD area alone, there were 3.5 million international or foreign students engaged in tertiary educational programmes in the year 2016. Different mobility programmes support students' mobility and aim at improving students' professional, cultural and language skills as well as students' international employability. International study 
mobility has become a key differentiating experience for students, and has gained increased policy attention (OECD, 2017). Students engage in study mobility for various reasons, predominantly to improve their professional skills and for personal growth (Juvan \& Lesjak, 2011). Nevertheless, recent research (for example, Lesjak et al., 2015) shows that factors specific to leisure travel play a highly important role in pursuing student mobility. Namely, being a tourist helps Erasmus mobility students to grow personally (for example, improve their understanding of a foreign culture or of nature, improve their ability to survive in a different environment, improve language skills, etc.).

The Erasmus+ mobility programme is a lot about travel. For example, Erasmus+ mobility students need to travel to a foreign country and, once in the host country, they explore the host as well as neighbouring countries (for example, Martinez-Roget et al., 2013; Gardiner et al., 2013; Pavlič \& Koderman, 2014); they pursue the role of tourists. Given the volume of travel involved during Erasmus+ mobility it is inevitable that not only educational but also travel-related attributes of host countries play an important role in students' decisions to pursue mobility (Lesjak et al., 2015). The empirical evidence about the size of the Erasmus+ mobility programme and the fact that Erasmus+ students do travel while at the host destination, makes them an interesting travel market. However, little is known about the travel behaviour and drivers of Erasmus+ students' travel behaviour during their mobility.

There is no doubt that hospitality is focused on nurturing of guests, providing them the best possible experience while they are our guests (Gorenak, 2019). That is why understanding travel behaviour and its key drivers improves the ability of destination marketing organisations as well as educational host institutions to personalise tourist experiences and inform approaches, thus improving destination competitiveness. More specifically, destination organisations can increase the attractiveness of places and educational institutions. Additionally, they can inform tourism providers about the Erasmus+ student's characteristics that effectively differentiate various segments and segment specific travel decisions (for example, choice of accommodation). While many different factors af- fect tourist behaviour (Moutinho, 1993; Pearce, 2015), and thus differentiate tourist segments, the most interesting for the industry are the factors which are easily identified with the specific market segment (Dolničar, 2008); for example, among the student population these would be gender, age and the level of studies.

Investigating students' travel behaviour is not new, however, understanding leisure travel behaviour of Erasmus+ students is still relatively unexplored. Existing studies predominantly investigate travel behaviour of a general student population, typically involving long-term international students, which differentiate from Erasmus+ students. The key differentiating variable is that Erasmus+ students reside in a host country for up to 6 months and their high interest in leisure travel (Lesjak et al., 2015). Following this conceptualisation, Erasmus+ students represent longer-staying tourists, engaged in studying as well as leisure travel. As such, Erasmus+ students should represent an international travel market of high interest to universities and tourism organisations, because both strive to attract this educational international market segment.

The present study aims at extending our current understanding of Erasmus+ students' travel behaviour by investigating the most typical travel decisions and their association with most evident and easily identified characteristics of students (gender and level of studies). The theoretical contribution of this study lies in improving the theory of tourist behaviour in the context of a medium-term international student's travel. Practically, this study informs (1) educational institutions about key destinations attributes important for attracting Erasmus+ mobility students and (2) destination marketing organisations and tourism providers about how to personalise typical tourism services and infrastructure as well as how to communicate leisure travel opportunities to the Erasmus+ student travel segment.

The manuscript continues by explaining the specifics of the Erasmus+ student mobility and drivers of students' travel behaviour. We then proceed by explaining the methodology of the empirical research and data analysis. The manuscript concludes with the discussion and key recommendations on how tourism 
industry and educational institutions can benefit by catering to the Erasmus+ student travel segment.

\section{Drivers of Students' Mobility and Tourist Behaviour}

Formal and informal learning are recognized as important behaviour drivers for young travellers, including students (UNWTO, 2008; 2016), who typically travel for more than 24 hours but less than one year, for the purpose of education. During such travels, students engage in different forms of tourism, for example volunteering, work and travel, cultural exchange, sports and adrenaline tourism; however, education remains their main motive (Moisa, 2010). More specifically, students can choose between various forms of educational tourism, such as study mobility exchanges, excursions, international research projects and international internships (van 't Klooster et al., 2008). Studying abroad has become an important personal investment as it brings an important competitive advantage once students enter the labour market (Moreira \& Gomes, 2019). Additionally, international students represent an important source of income for host destinations with everyday living expenses contributing to the local economy (OECD, 2017; Amaro et al., 2019).

Different reasons drive students' decisions for study mobility; the prevailing ones are improving employment opportunities, access to higher quality of education, learning about culture, improving foreign language skills and ensuring higher economic or social status in the future (Abubakar et al., 2014; Moreira \& Gomez, 2019). Several authors (for example, Ajanovic et al., 2016; Sova, 2017; Stone \& Petrick 2013; Vossensteyn et al., 2010) conceptualise students' mobility motives as personal and professional skills development, career opportunities, leisure, relaxation and other drivers. Juvan and Lesjak (2011) report that Slovenian student outgoing mobility is driven by a desire to gain international experience, a change of everyday environment, interesting study programmes offered by the host universities, improvement of language skills, recommendations from friends, and by the Erasmus grant. In general, international Erasmus travel is driven by the desire to experience something new, personal growth, to have fun and relax, visiting new places, learning about different cultures, meeting new people, spending a semester abroad, improving foreign language skills, experience a different education system, improve academic knowledge and increase job opportunities (Lesjak et al., 2015; Heung \& Leong, 2006; Kim, 2007).

Students consider a number of university and destination related attributes when making their mobility choices, for example welcoming attitudes of the local population, tuition fees and scholarships, security and quality of life in the host country, political instability in the home country, access to visas and proximity to the homeland (Juvan \& Lesjak, 2011; Abubakar et al., 2014). When choosing their mobility destination, students also look at the non-academic attributes of their host country. More specifically those perceived destination attributes are connected to rich natural attractions, safety and security, novelty, rich culture and history, a large number of different events, a high standard of living, nightlife, accessibility and others (Lesjak et al., 2015; Buffa, 2015). During their study, mobility students travel within and outside their host country and typically consider fun, costs and safety attributes of the tourism products and services (Vukić et al., 2015; Pavlič \& Koderman, 2014) as the key drivers of choices. North American and European students typically stay in cheaper forms of accommodation, while Chinese and Indian students opt more for traditional accommodations, such as hotels or motels (Michael et al., 2004).

Tourist behaviour typically involves tourists' choices of destination, accommodation infrastructure, and destination activities as well as booking tools. Besides that, tourists seek tourism services that make them feel at ease and relaxed (Gorenak et al., 2019). These choices greatly depend on the travel budget. Students, and in particular Erasmus+ students, pursue their tourist travel through the Erasmus+ exchange mobility system which supports students in evaluating tourist-related alternatives (one example of such support is the Erasmus+ grant, which financially supports students' travel-related choices). Students are a heterogeneous travel market, yet with some common characteristics (Richards \& Wilson, 2003). Prior stud- 
ies (Table 1) provide a wide range of, yet inconclusive, knowledge about how to attract and cater to the international Erasmus+ students travel market.

Based on the existing literature, it can be concluded that a number of easily identifiable characteristics of student travellers affect students' travel behaviour. More specifically, age (Hsu \& Sung, 1997; Kim \& Jogaratnam, 2003; Michael et al., 2004; Payne, 2009; Shoham et al., 2004; Varasteh et al., 2015), gender (Shoham et al., 2004; Kim \& Jogaratnam, 2003) and the level of study degree (Glover, 2011; Shoham et al., 2004; Payne, 2009; Varasteh et al., 2015). These characteristics typically drive the choices of accommodation (Michael et al., 2004; Kim \& Jogaratnam, 2003; Shoham et al., 2004) or influence travel motives and students' expenditure during the mobility (Payne, 2009; Varasteh et al., 2015). Marital status, nationality and sources of income affect travel preferences of international postgraduate students in Malaysia (Varasteh et al., 2015).

\section{Student Mobility: Erasmus+ Programme}

Student mobility is a form of educational mobility aimed at supporting enriching formal education by travelling to a foreign country and university. It enables students to grow professionally and personally, but also provides them with opportunities for leisure travel and escape from everyday life (Lesjak et al., 2015). Erasmust is a successor of the Erasmus programme (founded in 1987) for the period 2014-202O, which promotes education, training and sports in all sectors of a lifelong learning programme (European Commission, 2017). It was developed to provide easy access to a quality educational and multicultural experience for knowledge seekers and to modernise education, training and sport for youth across the Europe. It (1) offers a unique global educational experience catered to students seeking atypical ways of completing their formal education, at various levels of degree, (2) aims at increasing a sense of global citizenship in each participant, and (3) provides students with the opportunity to experience novel educational approaches for studying an already-chosen professional discipline. The Erasmus+ programme's aim is also to help develop a highly-skilled labour force, improving students' capabilities and skills and enhancing the European status of a knowledge-based economy (Gonzalez et al., 2011). Since its foundation, the Erasmus programme has supported educational travel for over 9 million individuals, of which over 5 million were students (European Commission, 2017).

In Slovenia, Erasmus+ and other student mobility programmes are managed by CMEPIUs (Center RS for Mobility and European Education and Training Programs) and movit, the two national agencies responsible for the implementation of the program in the period 2014. Table 2 demonstrates numbers of incoming and outgoing Erasmus+ students in Slovenia in the last decade. From the table it can be seen that the number of incoming students has more than doubled, while the number of outgoing students has risen by $30 \%$ from 2007 to 2017 .

\section{Methodology}

The present study investigates tourist behaviour (destination choice, accommodation choice, travel expenditure, transport choices, booking behaviour and perceived importance of destinations' attributes) of Erasmus+ students in Slovenia. A web survey was sent to all Erasmus+ enrolling students in the 2016/17 academic year, both to incoming and outgoing Erasmus+ students. The survey questionnaire was developed to measure tourist behaviour of Erasmus+ tourists. The survey questionnaire was developed in the English language and administered via the online survey tool 1ka. Prior to finalizing the instrument, questions and items were reviewed and discussed by a pilot group of 40 Erasmus+ students in order to justify and validate the items and to amend the wording so as to ensure the reliability and understanding of the queries and answer options for the Erasmus+ students' different levels of English language skills. As a result of this process, some unreliable statements were rephrased or excluded from the final version of the questionnaire. Questions used closed type binary and single or multi category answer options. The total population involved approximately 2500 Erasmus+ students from three major Slovenian universities (University of Ljubljana (UNI LJU), University of Maribor (UNI MB) and University of Primorska (UP)). The final sample 
Table 1 A Brief Bibliographic Study about Students' Tourism Behaviour and Its Drivers

\begin{tabular}{|c|c|c|c|c|c|c|c|}
\hline Reference & (1) & (2) & (3) & (4) & (4) & (5) & (6) \\
\hline $\begin{array}{l}\text { Gardiner et } \\
\text { al. (2013) }\end{array}$ & $\begin{array}{l}\text { QUAL, } \\
\text { QUAN }\end{array}$ & $\begin{array}{l}\text { International } \\
\text { students studying } \\
\text { in Australia }(N= \\
4366)\end{array}$ & Australia & $\begin{array}{l}\text { Hostel }(44 \%) \\
\text { Holiday A P P (23\%) } \\
\text { Hotels \& Motels (23\%) } \\
\text { Camps }(5 \%)\end{array}$ & - & AU\$ 500 & - \\
\hline $\begin{array}{l}\text { Varasteh et al. } \\
(2014)\end{array}$ & QUAN & $\begin{array}{l}\text { Malaysian stu- } \\
\text { dents }(N=409)\end{array}$ & Malaysia & - & - & - & $\begin{array}{l}\text { Touring } \\
\text { Attending events } \\
\text { Sports } \\
\text { Recreation } \\
\text { Resting }\end{array}$ \\
\hline $\begin{array}{l}\text { Lantai \& Mei, } \\
\text { X. Y. (2017) }\end{array}$ & QUAL & $\begin{array}{l}\text { Mainland Chi- } \\
\text { nese international } \\
\text { students }(N=15)\end{array}$ & Norway & $\begin{array}{l}\text { Homestays } \\
\text { Airbnb } \\
\text { Hostels }\end{array}$ & - & - & - \\
\hline $\begin{array}{l}\text { Michael et al. } \\
(2004)\end{array}$ & QUAN & $\begin{array}{l}\text { International } \\
\text { students studying } \\
\text { in Melbourne ( } N \\
=219)\end{array}$ & Australia & - & - & A $\$ 392$ & $\begin{array}{l}\text { Sightseeing (nat- } \\
\text { ural, manmade } \\
\text { attractions) } \\
\text { Shopping }\end{array}$ \\
\hline $\begin{array}{l}\text { Monteiro } \\
\text { \& Pereira } \\
(2016)\end{array}$ & QUAL & $\begin{array}{l}\text { Erasmus students } \\
(N=880)\end{array}$ & Portugal & $\begin{array}{l}\text { Youth hostel }(44 \%) \\
\text { Hotel }(27.5 \%) \\
\text { Housing with families } \\
(23.4 \%)\end{array}$ & - & - & - \\
\hline Glover (2011) & QUAL & $\begin{array}{l}\text { Domestic \& In- } \\
\text { ternational stud. } \\
(N=948)\end{array}$ & Australia & $\begin{array}{l}\text { Friends \& Relatives } \\
(26.9 \%) \\
\text { Backpacking }(27.9 \%)\end{array}$ & - & - & \\
\hline Payne (2009) & QUAN & $\begin{array}{l}\text { International stu- } \\
\text { dents on holidays } \\
(N=217)\end{array}$ & $\begin{array}{l}\text { New } \\
\text { Zealand }\end{array}$ & $\begin{array}{l}\text { Backpacking \& Hostel } \\
(28.8 \%) \\
\text { Family \& Friends } \\
(20.8 \%)\end{array}$ & - & $\begin{array}{l}\text { NZ\$ } \\
397.81- \\
688.77\end{array}$ & $\begin{array}{l}\text { Eating out }(60.6 \%) \\
\text { Beaches }(57.5 \%) \\
\text { Shopping }(40.9 \%)\end{array}$ \\
\hline $\begin{array}{l}\text { Shoham et al. } \\
(2004)\end{array}$ & QUAN & $\begin{array}{l}\text { Students }(N= \\
558)\end{array}$ & $\begin{array}{l}\text { US A, } \\
\text { South } \\
\text { Africa \& } \\
\text { Israel }\end{array}$ & $\begin{array}{l}\text { Hotels } \\
\text { Friends/family } \\
\text { B \& B } \\
\text { Camps } \\
\text { Hotels }\end{array}$ & - & - & $\begin{array}{l}\text { Entertainment } \\
\text { Sport } \\
\text { Culture } \\
\text { Nature }\end{array}$ \\
\hline $\begin{array}{l}\text { Weaver } \\
(2003)\end{array}$ & QUAN & $\begin{array}{l}\text { International } \\
\text { students (Hong } \\
\text { Kong, India, In- } \\
\text { donesia, Japan, } \\
\text { and Singapore) } \\
(N=139)\end{array}$ & $\begin{array}{l}\text { Within } \\
\text { Australia }\end{array}$ & $\begin{array}{l}\text { Motel }(35 \%) \\
\text { Hotel }(34 \%) \\
\text { Private home (29\%) } \\
\text { Hostel (20\%) } \\
\text { B \& B, guesthouse (9\%) } \\
\text { Camping (6\%). }\end{array}$ & $\begin{array}{l}\text { Package } \\
\text { tours }\end{array}$ & - & $\begin{array}{l}\text { Sightseeing } \\
\text { Recreation } \\
\text { Socialising }\end{array}$ \\
\hline $\begin{array}{l}\text { Xu et al. } \\
(2009)\end{array}$ & QUAN & $\begin{array}{l}\text { Students from the } \\
\text { UK }(N=239) \text { and } \\
\text { China }(N=286)\end{array}$ & $\begin{array}{l}\text { U K \& } \\
\text { China }\end{array}$ & $\begin{array}{l}\text { Hostels } \\
\text { Self-catering }\end{array}$ & - & - & $\begin{array}{l}\text { Outdoor } \\
\text { Sightseeing } \\
\text { Shopping } \\
\text { Entertainment }\end{array}$ \\
\hline
\end{tabular}

Notes Column headings are as follows: (1) methodology, (2) respondents, (3) destination, (4) accommodation, (5) booking tool, (6) expenditure, (7) activities. 
Table 2 Number of Incoming and Outgoing Erasmus+ Students 2007-2017, for Slovenia

\begin{tabular}{lrrrrrrrrrrrr}
\hline Year & 2007 & 2008 & 2009 & 2010 & 2011 & 2012 & 2013 & 2014 & 2015 & 2016 & 2017 & Total \\
\hline Incoming & 825 & 987 & 1138 & 1287 & 1516 & 1681 & 1677 & 1872 & 2257 & 2346 & 2097 & 17683 \\
Outgoing & 1018 & 1132 & 1118 & 1199 & 1411 & 1316 & 1277 & 1433 & 1421 & 1306 & 1311 & 13942 \\
\hline
\end{tabular}

Notes Based on data from cmepius (http://statistike.cmepius.si).

included 546 valid responses. In December 2017, researchers contacted the three Erasmus+ coordinators at the Slovenian universities with the request to send a survey invitation via email with the link to all their incoming and outgoing Erasmus+ students in academic year 2016/2017.

Building on existing youth travel, and specifically students' travel-related literature, the survey measured typical tourist choices of Erasmus+ students. More specifically, students were asked if they took any trip during their mobility (dichotomous variable; Yes, No), where they took the trip (nominal variable; domestic, international or domestic and international destination), where they typically stayed during their trip (nominal variable; hotel, motel, bed and breakfast, holiday apartment/holiday house/holiday cabin, private room, camping site, youth hostel/backpacker, holiday home owned by my family, other), how they typically booked their accommodation (nominal variable; couch surfing, AirBnB, online travel agent, walk-in travel agent, friends and relatives, directly with the provider, other), how much they spent on average per trip (ordinal variable; up to $310 €$, between 311 and 620 $€$, more than $621 €$ ), how they typically travelled to their destination (nominal variable; by air, by sea, by coach/bus, by car, by train, by motorbike, by bike) and how they typically booked their transportation (nominal variable; online travel agent, walk-in travel agent, other). Students were asked about the importance of destination attributes (interval variable; 1 meaning the attribute is not important at all, 5 meaning the motive is very important) in their choice of a travel destination. The following research hypotheses were built:

HYPOTHESIS 1 The gender and the type of study degree influence the tourist behaviour of the interviewed ERASMUS+ students.

HYPOTHESIS 2 The gender and the type of study degree influence the importance of the destination attributes for the interviewed ERASMUS+ students.

Frequency distributions were used to analyse Erasmus+ students' tourist behaviour. Chi square tests were used to infer relationships between tourist behaviour and socio-demographic characteristics (gender and type of degree) of students. Kramer's V test was used to indicate the strength of the association between the variables (Field, 2013). Given the use of the chi-square test, only responses with $N=30$ (the assumption of at least 5 units in each cell is needed in order for the test to be valid, thus, having at least 6 cells in each analysis, 30 units is the minimum assumption) or above on a single response option were included in statistical analysis to limit the effect of sample size (McHugh, 2013). A $t$-test was employed to infer differences between destination attributes and socio-demographic variables.

\section{Results}

$72 \%$ of the interviewed students were female, the rest were male students. $47.8 \%$ of participating students were undergraduate, while $52.2 \%$ of them were postgraduate (master or doctoral) students. More than half (51.6\%) of the surveyed students were incoming and $48.4 \%$ were outgoing students. The participating students' average age was just short of 24 years. When testing the associations between the gender and the degree of study (using the chi-square test) no statistical differences at the 0.05 level were found $\left(\chi^{2}=0.119\right.$, $p=0.730$ ). Table 3 demonstrates that Erasmus+ mobility students actively engage in travelling during their student mobility.

\section{Students' Travel Behaviour and Its Drivers}

The following section demonstrates the existing statistically significant differences between students' tourist 
Table 3 Erasmus+ Students Travel Behaviour

\begin{tabular}{|c|c|c|c|}
\hline Question & Answer & $f$ & $f \%$ \\
\hline \multirow{2}{*}{$\begin{array}{l}\text { Do Erasmus+ students make } \\
\text { leisure related travel? }\end{array}$} & Yes & 407 & 92.9 \\
\hline & No & 31 & 7.1 \\
\hline \multirow[t]{3}{*}{ Where Erasmus+ students travel? } & Only within Erasmus+ country & 92 & 22.8 \\
\hline & Only outside Erasmus+ country & 1 & 0.2 \\
\hline & Both, within and outside Erasmus+ country & 311 & 77.0 \\
\hline \multirow[t]{5}{*}{ Where Erasmus+ students stay? } & Hotel, motel, bed \& breakfast & 59 & 15.6 \\
\hline & Holiday apartment/holiday house/holiday cabin, private room/Airbnb & 82 & 21.6 \\
\hline & Camping site & 9 & 2.4 \\
\hline & Youth hostel/backpacker & 206 & $54 \cdot 4$ \\
\hline & Holiday home owned by my family or friends/couch surfing & 23 & 6.1 \\
\hline \multirow{4}{*}{$\begin{array}{l}\text { How Erasmus+ students book } \\
\text { their accommodation? }\end{array}$} & Couch surfing & 29 & 7.9 \\
\hline & Airbnb & 139 & 38.0 \\
\hline & Online travel agent & 164 & 44.8 \\
\hline & Friends and relatives & 34 & $9 \cdot 3$ \\
\hline \multirow{3}{*}{$\begin{array}{l}\text { How much Erasmus+ students } \\
\text { spend per trip? }\end{array}$} & Up to $310 €$ & 129 & $33 \cdot 9$ \\
\hline & Between $311 €$ and $620 €$ & 154 & 40.4 \\
\hline & $621 €$ and above & 98 & 25.7 \\
\hline \multirow{6}{*}{$\begin{array}{l}\text { How Erasmus+ students travel } \\
\text { to the trip destination? }\end{array}$} & By air (e.g. airplane, helicopter, etc.) & 80 & 19.9 \\
\hline & By sea (e.g. ship, boat, etc.) & 3 & 0.7 \\
\hline & By coach/bus & 130 & 32.3 \\
\hline & By car & 131 & 32.6 \\
\hline & By train & 55 & 13.7 \\
\hline & By bike & 3 & 0.7 \\
\hline \multirow{3}{*}{$\begin{array}{l}\text { How Erasmus+ student book } \\
\text { their transportation for trips? }\end{array}$} & Online travel agents/sites & 317 & 80.1 \\
\hline & Walk-in travel agents & 31 & 7.8 \\
\hline & Other & 48 & 12.1 \\
\hline
\end{tabular}

behaviour and their demographics. Table 4 demonstrates significant association between gender, type of degree and typical students' travel-related behaviour (detailed outputs are available in Tables 5 and 6).

A significantly higher number of the interviewed male students reported staying in hotels and similar establishments $(26.7 \%)$ as well as in private types of dwellings (e.g. apartments, holiday houses; $26.7 \%$ ) compared to the interviewed female students $(13.8 \%$ of the interviewed female students reported staying in hotels, motels or bed and breakfast; $22.3 \%$ of them stayed in private accommodation). On the other hand, a significantly higher number of the interviewed female students reported staying in dwellings typical for young travellers (e.g. youth hostels; 64\%) compared to the interviewed male Erasmus+ students (46.7\%). As a means of transportation to the destination, a significantly higher proportion of the interviewed male students reported using cars (42.4\%) compared to the interviewed female students $(28.6 \%)$, while the higher proportion of the interviewed female students reported using coaches or buses $(36.8 \%)$ compared 
Table 4 Students' Tourist Behaviour by Gender and Type of Study Degree

\begin{tabular}{lrrrrrrr}
\hline Behaviour/choices & \multicolumn{3}{c}{ Gender } & & \multicolumn{3}{c}{ Degree of study } \\
\cline { 2 - 5 } \cline { 5 - 8 } & $\chi^{2}$ & $p$ & Cramer $V$ & & $\chi^{2}$ & $p$ & Cramer $V$ \\
\hline Accommodation & 0.596 & 0.440 & 0.039 & 3.006 & 0.222 & 0.093 \\
Destination & 10.251 & 0.006 & 0.174 & 0.754 & 0.385 & 0.043 \\
Booking the accommodation & 0.916 & 0.633 & 0.053 & 2.463 & 0.292 & 0.085 \\
Expenditure & 3.746 & 0.176 & 0.096 & 10.347 & 0.006 & 0.165 \\
Transportation & 9.846 & 0.020 & 0.161 & 8.280 & 0.041 & 0.145 \\
Booking the transportation & 1.203 & 0.548 & 0.056 & 1.983 & 0.371 & 0.071 \\
\hline
\end{tabular}

Table 5 Students' Tourist Behaviour by Gender

\begin{tabular}{|c|c|c|c|c|c|c|}
\hline \multirow[t]{2}{*}{ Item } & \multirow[t]{2}{*}{ Behaviour/choices } & \multicolumn{2}{|c|}{ Percentage } & \multicolumn{3}{|c|}{ Test } \\
\hline & & Male & Female & $\chi^{2}$ & $p$ & Cramer $V$ \\
\hline \multirow[t]{2}{*}{ Destination } & Domestic & 19.6 & $23 \cdot 3$ & 0.596 & 0.440 & 0.039 \\
\hline & Domestic and international & 80.4 & 76.7 & & & \\
\hline \multirow[t]{3}{*}{ Accommodation } & Hotel, motel, bed \& breakfast & 26.7 & 13.8 & 10.251 & 0.006 & 0.174 \\
\hline & Holiday apartment ${ }^{*}$ & 26.7 & 22.3 & & & \\
\hline & Youth hostel/backpacker & 46.7 & 64.0 & & & \\
\hline \multirow[t]{3}{*}{ Booking the accommodation } & AirBnB & 39.3 & 41.8 & 0.916 & 0.633 & 0.053 \\
\hline & Online travel agent & 48.3 & 49.4 & & & \\
\hline & Friends and relatives & 12.4 & 8.9 & & & \\
\hline \multirow[t]{3}{*}{ Expenditure } & Up to 310 & 26.5 & 36.8 & 3.746 & 0.176 & 0.096 \\
\hline & From 310 to 610 & 43.9 & 38.9 & & & \\
\hline & 610 and above & 29.6 & $24 \cdot 3$ & & & \\
\hline \multirow[t]{4}{*}{ Transportation } & By air & 21.2 & 20.4 & 9.846 & 0.020 & 0.161 \\
\hline & By coach/bus & 21.2 & 36.8 & & & \\
\hline & By car & 42.4 & 28.6 & & & \\
\hline & By train & 15.2 & $14 \cdot 3$ & & & \\
\hline \multirow[t]{3}{*}{ Booking the transportation } & Online travel agent & 83.2 & 80.3 & 1.203 & 0.548 & 0.056 \\
\hline & Walk-in travel agent & 7.9 & 6.8 & & & \\
\hline & Other & 8.9 & 12.9 & & & \\
\hline
\end{tabular}

Notes $*$ Or holiday house, holiday cabin, private room or AirBnB.

to the interviewed male students $(21.2 \%)$. No statistically significant associations exist between gender and other investigated forms of travel behaviour (e.g. destination choice, booking the accommodation, type of transportation and expenditure).

The type of study degree appears to be significantly associated only with the trip expenditure of Erasmus+ students and the choice of transportation to the destination. A significantly higher proportion of the interviewed undergraduate students, compared to the interviewed postgraduate students, reported spending 610 EUR or more. $70 \%$ of the interviewed under- 
Table 6 Students' Tourist Behaviour by the Type of Study Degree

\begin{tabular}{|c|c|c|c|c|c|c|}
\hline \multirow[t]{2}{*}{ Item } & \multirow[t]{2}{*}{ Behaviour/choices } & \multicolumn{2}{|c|}{ Percentage } & \multicolumn{3}{|c|}{ Test } \\
\hline & & (1) & (2) & $\chi^{2}$ & $p$ & Cramer $V$ \\
\hline \multirow[t]{2}{*}{ Destination } & Domestic & 21.0 & 24.6 & 0.754 & 0.385 & 0.043 \\
\hline & Domestic and international & 79.0 & 75.4 & & & \\
\hline \multirow[t]{3}{*}{ Accommodaton } & Hotel, motel, bed \& breakfast & $15 \cdot 3$ & 18.8 & 3.006 & 0.222 & 0.093 \\
\hline & Holiday apartment* & 20.9 & 26.5 & & & \\
\hline & Youth hostel/backpacker & 63.8 & 54.7 & & & \\
\hline \multirow[t]{3}{*}{ Booking the accommodation } & Airbnb & 43.5 & 38.9 & 2.463 & 0.292 & 0.085 \\
\hline & Online travel agent & 48.8 & 48.5 & & & \\
\hline & Friends and relatives & 7.6 & 12.6 & & & \\
\hline \multirow[t]{3}{*}{ Expenditure } & Up to 310 & 29.8 & 37.8 & 10.347 & 0.006 & 0.165 \\
\hline & From 310 to 610 & 37.2 & $43 \cdot 5$ & & & \\
\hline & 610 and above & 33.0 & 18.7 & & & \\
\hline \multirow[t]{4}{*}{ Transportation } & By air & 23.9 & 16.6 & 8.280 & 0.041 & 0.145 \\
\hline & By coach/bus & 27.9 & 37.7 & & & \\
\hline & By car & 36.5 & 29.6 & & & \\
\hline & By train & 11.7 & 16.1 & & & \\
\hline \multirow[t]{3}{*}{ Booking the transportation } & Online travel agent & 79.2 & 80.9 & 1.983 & 0.371 & 0.071 \\
\hline & Walk-in travel agent & 9.6 & 6.0 & & & \\
\hline & Other & 11.2 & 13.1 & & & \\
\hline
\end{tabular}

Notes * Or holiday house, holiday cabin, private room or AirBnB; (1) undergraduate, (2) postgraduate.

graduate students spent more than 310 E UR per trip, while just $10 \%$ less interviewed postgraduate students reported similar expenditure per trip.

Statistically significant differences exist between the level of studies and the choice of transportation to the destination. More specifically, a significantly higher proportion of the interviewed undergraduate students reported using air transportation and cars to reach their travel destination. In contrast, a significantly higher proportion of the interviewed postgraduate students reported using coaches or buses and trains.

Empirical evidence shows no significant associations between the type of degree and other measured forms of the Erasmus+ students' tourist behaviour.

Results partially support Hypothesis 1 . The gender of the interviewed students statistically significant influences only the choice of the destination and the type of the transportation at the destination, while the degree of study statistically significant influences the total expenditure at the destination and the type of transportation at the destination.

\section{Destination Attributes and its Drivers}

The following section reports the association of perceived importance of destination attributes with the gender and the type of the degree (see Tables 8 and 9 for detailed outputs). The most important destination attributes overall (Table 7 ) are the natural ( $\mathrm{M}$ $=4.18)$ and cultural $(\mathrm{M}=4.14)$ attractions and sites. Other important attributes for choosing the destination are safety and security $(\mathrm{M}=3.84)$, cheap to visit $(M=3.76)$, easily accessible $(M=3.68)$ and cheap to live in $(\mathrm{M}=3.57)$. Attributes less important to the students are the destination's popularity $(M=2.57)$, high living standard $(\mathrm{M}=2.61)$ and familiar lifestyle $(\mathrm{M}=$ 
Table 7 Perceived Destination Attributes by Gender and Type of Study Degree

\begin{tabular}{|c|c|c|c|c|}
\hline \multirow[t]{2}{*}{ Item } & \multicolumn{2}{|c|}{ Gender } & \multicolumn{2}{|c|}{ Degree of study } \\
\hline & $t$ & sig. & $t$ & sig. \\
\hline Destination is very popular & 1.135 & 0.257 & 1.471 & 0.142 \\
\hline Destination offers cultural attractions and sites & -2.596 & 0.010 & -0.117 & 0.907 \\
\hline Destination offers events & 0.407 & 0.684 & 1.245 & 0.214 \\
\hline Destination is cheap to visit & 0.809 & 0.419 & 0.469 & 0.639 \\
\hline Destination is yet to be discovered by tourists & -0.010 & 0.992 & 1.316 & 0.189 \\
\hline Destination is easy accessible & -2.200 & 0.029 & 0.449 & 0.653 \\
\hline Destination is safe and secure & -1.995 & 0.048 & 0.209 & 0.834 \\
\hline Destination offers interesting night life & 2.112 & 0.035 & 3.778 & 0.001 \\
\hline At destination they speak language which I know & 0.359 & 0.720 & -1.025 & 0.306 \\
\hline Destination is sustainably oriented & -0.837 & 0.403 & 1.827 & 0.068 \\
\hline Destination has high living standard & 1.407 & 0.160 & -0.071 & 0.943 \\
\hline Destination is cheap to live in & 0.627 & 0.531 & 1.790 & 0.074 \\
\hline Destination offers a lifestyle which I am familiar with & 0.670 & 0.478 & -1.992 & 0.047 \\
\hline
\end{tabular}

2.68). In almost all cases of the variable destination attributes the skewness and kurtosis statistics show a distribution similar to the normal one (in the interval \pm ). Responses on the importance of 'destination offers natural attractions and sites' suggest distribution that is not close to a normal one (kurtosis $=2.319$ ); hence we decided to omit this attribute from further statistical analysis.

Four of the measured 13 destination attributes are significantly different by gender. More specifically, the interviewed female students placed significantly higher importance on cultural attractions $(\mathrm{M}=4.21, p$ $=0.01)$, ease of access $(\mathrm{M}=3.74, p=0.02)$, and safety and security $(\mathrm{M}=3.90, p=0.04)$ than the interviewed male students. However, the interviewed male students placed significantly higher importance on interesting nightlife $(\mathrm{M}=3.18, p=0.03)$ than the interviewed female students. The gender of the interviewed students does not significantly affect other measured destination attributes.

Only two destination attributes appear to be significantly different by the type of the study degree. The interviewed bachelor Erasmus+ students placed significantly higher importance on destinations' interesting nightlife $(\mathrm{M}=3.22, p=0.001)$ but the interviewed masters and $\mathrm{PhD}$ students placed significantly higher importance on familiar lifestyle $(\mathrm{M}=2.77, \mathrm{P}=0.047)$. No other significant differences exist between the type of degree and the perceived importance of the destination's attributes.

Hypothesis 2 claims that the gender and the degree of study of the interviewed students influence the perceived importance of destination attributes. Results just partially support the stated hypothesis. The gender of the interviewed students statistically significant influences some of the above-mentioned perceived importance of destination attributes, such as the fact that the destination offers cultural attractions and sites, that the destination is easy accessible, that it is safe and secure and that it offers an interesting nightlife. The degree of study of the interviewed students statistically significant influences the perceived importance of destination attribute that the destination offers an interesting nightlife and that the destination offers a lifestyle they are familiar with.

\section{Discussion}

Erasmus+ students generate an important share of the international tourist market, and studying abroad appears among the top travel motives of the younger 
Table 8 Associations between Destinations Attributes and Gender

\begin{tabular}{|c|c|c|c|c|c|}
\hline Item & Gender & $\mathrm{N}$ & Mean & $\mathrm{t}$ & sig. \\
\hline \multirow[t]{2}{*}{ Destination is very popular } & Male & 116 & 2.64 & 1.135 & 0.257 \\
\hline & Female & 301 & 2.52 & & \\
\hline \multirow[t]{2}{*}{ Destination offers cultural attractions and sites } & Male & 116 & 4.01 & -2.596 & 0.010 \\
\hline & Female & 303 & 4.21 & & \\
\hline \multirow[t]{2}{*}{ Destination offers events } & Male & 116 & $3 \cdot 37$ & 0.407 & 0.684 \\
\hline & Female & 302 & $3 \cdot 33$ & & \\
\hline \multirow[t]{2}{*}{ Destination is cheap to visit } & Male & 115 & 3.83 & 0.809 & 0.419 \\
\hline & Female & 302 & 3.75 & & \\
\hline \multirow[t]{2}{*}{ Destination is yet to be discovered by tourists } & Male & 116 & 3.18 & -0.010 & 0.992 \\
\hline & Female & 302 & 3.18 & & \\
\hline \multirow[t]{2}{*}{ Destination is easy accessible } & Male & 117 & 3.51 & -2.200 & 0.029 \\
\hline & Female & 302 & 3.74 & & \\
\hline \multirow[t]{2}{*}{ Destination is safe and secure } & Male & 116 & 3.68 & -1.995 & 0.048 \\
\hline & Female & 300 & 3.90 & & \\
\hline \multirow[t]{2}{*}{ Destination offers interesting night life } & Male & 115 & 3.18 & 2.112 & 0.035 \\
\hline & Female & 302 & 2.94 & & \\
\hline \multirow[t]{2}{*}{ At destination they speak language which I know } & Male & 116 & 2.93 & 0.359 & 0.720 \\
\hline & Female & 303 & 2.88 & & \\
\hline \multirow[t]{2}{*}{ Destination is sustainably oriented } & Male & 115 & 3.10 & -0.837 & 0.403 \\
\hline & Female & 302 & 3.19 & & \\
\hline \multirow[t]{2}{*}{ Destination has high living standard } & Male & 116 & 2.72 & 1.407 & 0.160 \\
\hline & Female & 302 & 2.57 & & \\
\hline \multirow[t]{2}{*}{ Destination is cheap to live in } & Male & 116 & 3.59 & 0.627 & 0.531 \\
\hline & Female & 302 & 3.53 & & \\
\hline \multirow[t]{2}{*}{ Destination offers a lifestyle which I am familiar with } & Male & 116 & 2.73 & 0.670 & 0.478 \\
\hline & Female & 302 & 2.65 & & \\
\hline
\end{tabular}

generation. Youth travel (both study and educational travel) is becoming a stable ongoing industry, contributing over $20 \%$ of international travel flow, which is equal to 207 million arrivals and $\$ 194$ billion expenditure in the year 2012 (see http://www.studentmarket.com/youth-travel). The number of international trips of young people based on the UnwTo forecast might increase to almost 370 million by 2020 for a total expenditure of over 400 billion dollars (Global Report on The Power of Youth Travel, 2016). Consequently, it is deemed relevant to investigate Eras- mus+ students' tourist behaviour and infer factors significantly associated with typical tourist behaviour.

The present study empirically supports that Erasmus+ students are an active and large travelling segment, with over $90 \%$ of respondents reporting travelling during their mobility. The travel industry sector sells most of its products and services via the internet (Abou-Shouk et al., 2013) and millennials are the first generation born to be living continuously with various technology options every day. Therefore, they could be described as e-travellers who are 
Table 9 Associations between Destinations Attributes and Type of Study Degree

\begin{tabular}{|c|c|c|c|c|c|}
\hline Item & Level of degree & $\mathrm{N}$ & Mean & $\mathrm{t}$ & sig. \\
\hline \multirow[t]{2}{*}{ Destination is very popular } & (1) & 221 & 2.64 & 1.471 & 0.142 \\
\hline & (2) & 234 & 2.50 & & \\
\hline \multirow[t]{2}{*}{ Destination offers cultural attractions and sites } & (1) & 221 & 4.14 & -0.117 & 0.907 \\
\hline & (2) & 236 & 4.14 & & \\
\hline \multirow[t]{2}{*}{ Destination offers events } & (1) & 222 & 3.41 & 1.245 & 0.214 \\
\hline & (2) & 235 & 3.30 & & \\
\hline \multirow[t]{2}{*}{ Destination is cheap to visit } & (1) & 220 & 3.78 & 0.469 & 0.639 \\
\hline & (2) & 235 & 3.74 & & \\
\hline \multirow[t]{2}{*}{ Destination is yet to be discovered by tourists } & (1) & 221 & 3.25 & 1.316 & 0.189 \\
\hline & (2) & 235 & 3.13 & & \\
\hline \multirow[t]{2}{*}{ Destination is easy accessible } & (1) & 222 & 3.70 & 0.449 & 0.653 \\
\hline & (2) & 235 & 3.66 & & \\
\hline \multirow[t]{2}{*}{ Destination is safe and secure } & (1) & 221 & 3.85 & 0.209 & 0.834 \\
\hline & (2) & 233 & 3.83 & & \\
\hline \multirow[t]{2}{*}{ Destination offers interesting night life } & (1) & 220 & 3.22 & 3.778 & 0.001 \\
\hline & (2) & 235 & 2.84 & & \\
\hline \multirow[t]{2}{*}{ At destination they speak language which I know } & (1) & 222 & 2.86 & -1.025 & 0.306 \\
\hline & (2) & 236 & 2.98 & & \\
\hline \multirow[t]{2}{*}{ Destination is sustainably oriented } & (1) & 222 & 3.25 & 1.827 & 0.068 \\
\hline & $(2)$ & 234 & 3.09 & & \\
\hline \multirow[t]{2}{*}{ Destination has high living standard } & (1) & 221 & 2.60 & -0.071 & 0.943 \\
\hline & $(2)$ & 235 & 2.61 & & \\
\hline \multirow[t]{2}{*}{ Destination is cheap to live in } & (1) & 222 & 3.65 & 1.790 & 0.074 \\
\hline & (2) & 235 & 3.49 & & \\
\hline \multirow[t]{2}{*}{ Destination offers a lifestyle which I am familiar with } & (1) & 221 & 2.58 & -1.992 & 0.047 \\
\hline & (2) & 235 & 2.77 & & \\
\hline
\end{tabular}

Notes (1) Bachelor degree, (2) Master/PhD/doctoral degree.

constantly connected to the internet via their gadgets (smart phones, tablets, etc.) either searching for travel information or booking holidays (Huang \& Petrick, 2010). Travelling Erasmus+ students are extensive users of e-tourism infrastructure, both to inform and purchase travel services. About $40 \%$ of respondents book their accommodation through an online travel agency and $36.8 \%$ of respondents book accommodation using the Airbnb P2P platform. Erasmus+ students' travel choices significantly depend on gen- der and type of the degree, making these attributes the most suitable for identifying and targeting Erasmus travellers with personalised tourism offerings. More specifically, the choices of accommodation depend solely on gender, but transportation choices depend on the gender and the type of degree. In addition, the type of the degree demonstrates significant association with the student's destination-based travel expenditure. More specifically, the interviewed female Erasmus+ students are more likely to stay in 
youth hostels, backpackers, family homes and with friends and relatives. However, the interviewed male Erasmus+ students prefer traditional commercial accommodation dwellings such as hotels, motels, bed and breakfast, and private rooms. These findings suggest that universities as well as destinations' marketing organisations should work together in developing and promoting gender-customized accommodation infrastructure and their promotion as well as distribution channels. For example, they could promote and provide typical tourism accommodation to male students, but low-budget types of dwellings for female students.

Moreover, undergraduate students appear to be more lucrative to the tourism industry than their graduate counterparts are; the latter segment has significantly fewer students spending over 610 Eur. Every Erasmus+ student receives a living allowance for their stay in a foreign country; however, it may be that undergraduate students receive higher financial support from their parents as they predominantly depend on them (Souto-Otero, 2008). The Erasmus+ allowance and their parents' financial support improve undergraduate disposable income, which students can use for tourism purposes. In addition, graduate students predominantly seek fulfilment of professional rather than personal goals, and thus have lower desire for leisure travel (Brooks \& Waters, 2009), which may result in lower spending for vacations. The findings about expenditure usefully contribute to existing knowledge about students' travel expenditure and more specifically, our findings suggest that Erasmus+ students may be better spenders than other types of international students (for example, Payne, 2009; Gardiner et al., 2013).

Destination attributes play an important role in leisure travel, as they represent characteristics of tourist places that tourists find most important when making travel-related decisions; yet, tourist segments differ in the perceived importance of destination attributes (Um \& Crompton, 1992; Meng \& Uysal, 2008). Understanding what Erasmus+ travellers find important at the destination and how this importance depends on students' personal characteristics allows destination marketing organisations as well as universities to develop and communicate relevant destination attributes. Overall, Erasmus+ travellers find cultural and natural attractions as well as safety to be the most important attributes of their chosen destinations. These attributes are followed by costs of visiting and living; thus rounding up the most typical attributes important to the mainstream travel market (Um \& Crompton, 1992). Familiar lifestyle, living standard and familiar langue seem to have less importance when evaluating destination alternatives.

The perceived importance for some of the attributes changes between gender and the type of degree; hence suggesting different approaches when targeting students of different gender and type of degree. More specifically, having cultural attractions and sites makes a destination significantly more attractive to female, than to male students. Compared to male students, female students place significantly higher importance on destination transport accessibility and to the level of safety and security. In contrast, male students rate interesting nightlife opportunities significantly higher than female students. Looking at gender, a typical female Erasmus+ student prefers a destination that is easily accessible, is safe and has attractive cultural sites and attractions. A typical male Erasmus+ student predominantly seeks destinations with attractive nightlife opportunities.

Two research hypotheses were tested in this paper. The first one states that the gender and the degree of study of the interviewed students influences the students' travel behaviour. Results just partially support the above-mentioned research hypotheses. More interviewed male students reported staying in hotels and similar establishments $(\mathbf{2 6 . 7 \% )}$ as well as in private types of dwellings (e.g. apartments, holiday houses; $26.7 \%$ ), while a higher number of the interviewed female students reported staying in dwellings typical for young travellers (e.g. youth hostels; 64\%). A higher proportion of the interviewed male students reported using cars $(42.4 \%)$, while a higher proportion of the interviewed female students reported using coaches or buses $(36.8 \%)$. A higher proportion of the interviewed undergraduate students, compared to the interviewed postgraduate students, reported spending 610 EUR or more. $70 \%$ of the interviewed under- 
graduate students spent more than 310 EUR per trip, while just $10 \%$ less interviewed postgraduate students reported similar expenditure per trip. A higher proportion of the interviewed undergraduate students reported using air transportation and cars to reach their travel destination, while a higher proportion of the interviewed postgraduate students reported using coaches or buses and trains. Hypothesis 2 claims that the gender and the degree of study of the interviewed students influences their perception of the destination attributes. The research hypothesis can be just partially supported by the results. The interviewed female students placed significantly higher importance on cultural attractions $(\mathrm{M}=4.21, p=0.01)$, ease of access $(\mathrm{M}=3.74, p=0.02)$, safety and security $(\mathrm{M}=$ 3.90, $p=0.04$ ) than the interviewed male students. However, the interviewed male students placed significantly higher importance on interesting nightlife ( $\mathrm{M}$ $=3.18, p=0.03)$ than the interviewed female students. The interviewed bachelor Erasmus+ students placed significantly higher importance on destinations' interesting nightlife $(\mathrm{M}=3.22, p=0.001)$ but the interviewed masters and $\mathrm{PhD}$ students placed significantly higher importance on familiar lifestyle $(\mathrm{M}=2.77, p=$ o.047).

\section{Conclusions}

Educational tourism is one of the fastest-growing forms of tourism and has become a multimilliondollar industry (Payne, 2009); however, the tourism professionals and destination organisation marketers too often overlook it. Erasmus+ travellers, especially students, engage in tourism while on their mobility and they need personalised infrastructure and resources for successful engagement in tourism. This requires that the tourism industry collaborates with various educational institutions to understand students' needs, their capabilities and tourism-related behaviour. Thus, universities are an important player for destination-based tourism, because they provide the tourism demand. Even more, it appears that knowledge provision is no longer the most important competitive product of universities (Juvan \& Lesjak, 2011) and that universities must collaborate with providers of other attributes within their places (for example, cultural attractions or interesting nightlife). This calls for increased collaboration between universities, as knowledge providers, and destination marketing organisations, as tourist opportunity providers.

Two key conclusions derive from the present research. First, the Erasmus+ travel market is growing and is distinct from the mainstream travel market and second, at least gender and level of degree make the Erasmus+ travel market heterogenic. The first conclusion points to the need for the travel industry and universities to collaborate in marketing destinations and universities. The second conclusion suggests a personalised destination marketing mix when catering to travel planning and destination-based behaviour of Erasmus+ students. In addition, the study offers an important insight for the future research on Erasmus+ students. While educational aspects of Erasmus+ students' mobility are well covered in scientific literature, a lack of empirical evidence about Erasmus+ students' travel behaviour exists. The present study extends our empirically-derived knowledge on Erasmus+ students' typical tourism behaviour and characteristics of the Erasmus+ travel market that warrant distinctive tourism development and promotion approaches when catering to Erasmus+ travellers.

The key limitation of the study lies in the geographic dimension of the study sample. Conclusions that could be more generalisable would require a geographically more diverse and representative sample of Erasmus+ students. Thus, we recommend expanding the research to all countries participating in the Erasmus+ programme. Further, we advocate more research focused on the leisure travel aspects of Erasmus+ mobility, not only direct travel by the Erasmus+ mobility students, but also the travel behaviour of individuals socialising with Erasmus+ mobility students.

\section{References}

Abou-Shouk, M., Lim, W. M., \& Megicks, P. (2013). Internet adoption by travel agents: A case of Egypt. International Journal of Tourism Research, 15(3), 298-312.

Abubakar, A. M., Shneikat, B. H. T., \& Oday, A. (2014). Motivational factors for educational tourism: A case study in Northern Cyprus. Tourism Management Perspectives, $11,58-62$.

Ajanovic, E., Çizel, B., \& Çizel, R. (2016). Effectiveness of 
Erasmus programme in prejudice reduction: Contact theory perspective. The Business of Tourism, 17, 47-6o.

Amaro, S., Barroco, C., Martins, C., \& Antunes, J. (2019). Erasmus students in Portugal: From students to tourists and advocates. European Journal of Tourism Research, 22, 94-106.

Brooks, R., \& Waters, J. (2009). International higher education and the mobility of $\mathrm{UK}$ students. Journal of Research on International Education, 8(2), 191-209.

Buffa, F. (2015). Young tourists and sustainability: Profiles, attitudes, and implications for destination strategies. Sustainability, 7(10), 14042-14062.

Dolničar, S. (2008). Market segmentation in tourism. In A. Woodside \& D. Martin (Eds.), Tourism management: Analysis, behaviour and strategy (pp. 129-150). С А В I.

European Commission. (2017). Erasmus+ Programme Guide. http://ec.europa.eu/programmes/erasmus-plus/sites/ erasmusplus/files/files/resources/erasmus-plus -programme-guide_en.pdf

Field, A. (2013). Discovering statistics using IBM SPSs statistics: And sex and drugs and rock'n'roll (4th Edition). Sage.

Gardiner, S., King, B., \& Wilkins, H. (2013). The travel behaviours of international students: Nationality-based constraints and opportunities. Journal of Vacation Marketing, 19(4), 287-99.

Glover, P. (2011). A comparison between domestic and international students' trip characteristics: evidence from an Australian university. Journal of Vacation Marketing, $17(4), 263-274$.

Gonzalez, C. R., Mesanza, R. B., \& Mariel, P. (2011). The determinants of international student mobility flows: An empirical study on the Erasmus programme. Higher $E d$ ucation, 62(4), 413-430.

Gorenak, M. (2019). The differences in perceptions of organisational values in the hospitality sector: What do they tell us? Academica Turistica, 12(1), 73-83.

Gorenak, M., Špindler, T., \& Brumen, B. (2019). The influence of competencies of managers on job satisfaction of employees in the hotel industry. Organizacija: revija $z a$ management, informatiko in kadre, 52(2), 81-94.

Heung, V. C. S., \& Leong, J. S. L. (2006). Travel demand and behavior of university students in Hong Kong. Asia Pacific Journal of Tourism Research, 11(1), 81-96.

Hsu, C. H., \& Sung S. (1997). Travel behaviors of international students at a Midwestern university. Journal of Travel Research, 36(1), 59-65.

Huang Y.-C., \& Petrick, J. F. (2010). Generation Y's travel behaviours: A comparison with Baby boomers and generation X. In P. Benckendorff, G. Moscardo, \& D. Ponder- gast (Eds.), Tourism and generation $Y$ (pp. 27-37). С А В International.

Juvan, E., \& Lesjak, M. (2011). Erasmus Exchange Program: Opportunity for professional growth or sponsored vacations? Journal of Hospitality \& Tourism Education, 23(2), 23-29.

Kim, K. (2007). Understanding differences in tourist motivation between domestic and international travel: The university student market. Tourism Analysis, 12(1-2), 65-75.

Kim, K., \& Jogaratnam, G. (2003). Activity preferences of Asian international and domestic American university students: An alternative basis for segmentation. Journal of Vacation Marketing, 9(3), 260-270.

Lantai, T., \& Mei, X. Y. (2017). Travel behaviour of Mainland Chinese international students in Norway. Anatolia, 28(3), 394-403.

Lesjak, M., Juvan, E., Ineson, E. M., Yap, M. H. T., \& Axelsson, E. P. (2015). Erasmus student motivation: Why and where to go? Higher Education, 7o(5), 845-865.

Martinez-Roget, F., Pawlowska, E., \& Rodríguez, X. A. (2013). The economic impact of academic tourism in Galicia, Spain. Tourism Economics, 19(5), 1139-1153.

McHugh, M. L. (2013). The chi-square test of independence. Biochemia Medica, 23(2), 143-149.

Meng, F., \& Uysal, M. (2008). Effects of gender differences on perceptions of destination attributes, motivations, and travel values: An examination of a nature-based resort destination. Journal of Sustainable Tourism, 16(4), 445466.

Michael, I., Armstrong, A., \& King, B. (2004). The travel behaviour of international students: The relationship between studying abroad and their choice of tourist destination. Journal of Vacation Marketing, 10(1), 57-66.

Moisa, C. O. (2010). Aspects of the youth travel demand. Annales Universitatis Apulensis: Series Oeconomica, 12(2), 575-582.

Monteiro, A., \& Pereira, A. (2016). Erasmus student travel motivations: A factor-cluster segmentation approach. Turismo: Estudos \& Práticas, 5(1), 7-39.

Moreira, L., \& R. Gomes (2019). Study abroad: The influence of city and university attractiveness factors. European Journal of Tourism Research, 22, 79-93.

Moutinho, L. (1993). Consumer behaviour in tourism. European Journal of Marketing, 21(10), 5-44.

OECD. (2017). Education at a glance 2018: OECD indicators. OECD Publishing.

Pavlič, M., \& Koderman, M. (2014). Mladinski turizem in potovalne navade študentov - primer Univerze na Primorskem. Geografski vestnik, 86(1), 63-73. 
Payne, K. (2009). International students as domestic tourists in New Zealand: A study of travel patterns, behaviours, motivations and expenditure. Southern Cross University.

Pearce, P. L. (2015). Tourist behaviour: Themes and conceptual schemes. Multilingual Matters.

Richards, G., \& Wilson, J. (2003). Today's youth travellers: Tomorrow's global nomads (A report for the international Student Travel Confederation and the Association of Tourism and Leisure Education). International Student Travel Confederation.

Shoham A., Schrage C., \& van Eeden S. (2004). Student travel behavior: A cross-national survey. Journal of travel and Tourism Marketing, 17(4), 1-10.

Souto-Otero, M. (2008). The socio-economic background of Erasmus students: A trend towards wider inclusion? International Review of Education, 54(2), 135-154.

Sova, R. B. (2017). Understanding Erasmus students' motivation: What directs erasmus students' choice of destination and particular course. New Educational Review, 50(4), 26-35.

Stone, M. J., \& Petrick, J. F. (2013). The educational benefits of travel experiences: A literature review. Journal of Travel Research, 52(6), 731-744.

Um, S., \& Crompton, J. L. (1992). The roles of perceived inhibitors and facilitators in pleasure travel destination decisions. Journal of Travel Research, 3o(3), 18-25.

UNW TO. (2008). The power of youth travel. http://cf.cdn. unwto.org/sites/all/files/pdf/amreports_vol2 _thepowerofyouthtourism_eng_lw.pdf
UNWTO. (2016). Global report on the power of youth travel. https://www.wysetc.org/wp-content/uploads/2016/o3/ Global-Report_Power-of-Youth-Travel_2016.pdf

van 't Klooster, E., J. Van Wijk, F. M. Go, and J. van Rekom (2008). Educational travel: The overseas internship. Annals of Tourism Research, 35(3), 690-711.

Varasteh, H., Marzuki, A., \& Rasoolimanesh, S. M. (2015). Factors affecting international students' travel behavior. Journal of Vacation Marketing, 21(2), 131-149.

Vossensteyn, H., Beerkens, M., Cremonini, L., Besancon, B., Focken, N., Leurs, B., McCoshan, A., Huisman, J., Mozuraityte, N., Souto-Otero, M., \& de Wit, H. (2010). Improving the participation in the ERASMUS programme. Directorate-General for Internal Policies of the European Parliament.

Vukić M., Kuzmanović M., \& Kostić-Stanković M. (2015). Understanding the heterogeneity of generation Y's preferences for travelling: A conjoint analysis approach. International Journal of Tourism Research, 17(5), 482-491.

Weaver, D. (2003). The contribution of international students to tourism beyond the core educational experience: Evidence from Australia. Tourism Review International, 7(2), 95-105.

Xu, F., Morgan, M., \& Song P. (2009). Students travel behaviour: A cross-cultural comparison of $\mathrm{UK}$ and China. International Journal of Tourism Research, 11(3), 255-268. 